\title{
EFEKTIVITAS PENYELESAIAN DAN PENERIMAAN ATAS HASIL PEMERIKSAAN \\ PAJAK PENGHASILAN ORANG PRIBADI \\ (Studi Kasus KPP Pratama Manado)
}

\author{
Fino Indra Sumampouw \\ Inggriani Elim \\ Heince Wokas
}

Fakultas Ekonomi dan Bisnis Jurusan Akuntansi
Universitas Sam Ratulangi Manado
email : sumampouw_indra@yahoo.com

\begin{abstract}
ABSTRAK
Pemeriksaan pajak merupakan serangkaian kegiatan untuk mencari, mengumpulkan, mengolah data dan atau keterangan lainnya untuk menguji kepatuhan pemenuhan kewajiban perpajakan dan untuk tujuan lain dalam rangka melaksanakan ketentuan peraturan perundang-undangan perpajakan. Hal ini juga dilatar belakangi dengan Undang-undang perpajakan di Indonesia saat ini dalam melaksanakan pemungutan pajak menganut sistem self assessment. Hasil penghitungan Efektivitas pelaksanaan pemeriksaan pajak penghasilan khususnya $\mathrm{PPh}$ orang pribadi dan realisasi Surat Perintah Pemeriksaan (SP2) Pajak di KPP Pratama Manado, dari segi penyelesaian yang dihitung berdasarkan pada penerbitan dan realisasi (SP2) Pajak yang selesai, dimana tahun 2010-2012 mempunyai tingkat efektivitas yang sama yaitu termasuk dalam kriteria efektif dengan presentase $100 \%$ dan Hasil penghitungan efektivitas dari segi penyelesaian penerimaan atas hasil pemeriksaan yang dihitung berdasarkan target dan realisasi SP2 Pajak, dimana mempunyai tingkat Efektivitas pada tahun 2010 $(101,8 \%)$, tahun $2011(103,4 \%)$, dan tahun $2012(113,1 \%)$ yang semuanya termasuk dalam kriteria sangat efektif. Itu berarti bahwa kinerja dari KPP Pratama Manado sudah sangat baik karena dapat memenuhi target yang telah ditentukan, dan sebaiknya KPP Pratama Manado dapat terus mempertahankannya.
\end{abstract}

Kata Kunci : Pajak, Efektivitas, Pemeriksaan, Penyelesaian, Penerimaan.

\begin{abstract}
Tax audit is a series of activities to search for, collect, and process data or other information to verify compliance fulfillment of tax obligations and for other purposes in order to implement the provisions of the tax legislation. It is also against the background of the tax laws in Indonesia in implementing tax collection embrace self assessment system. The effectiveness of the implementation of the inspection results of the calculation of income tax and the individual income tax in particular the realization of Inspection Warrant (SP2) Tax on KPP Pratama Manado, in terms of the settlement are calculated based on the issuance and realization (SP2) Tax is completed, which have a higher effectiveness 2010-2012 the same is included in the criteria effectively with a percentage of $100 \%$ and the results of the calculation in terms of the effectiveness of the completion of the acceptance of the results of the examination are calculated based on the target and the realization SP2 Tax, which had a degree of effectiveness in 2010 (101.8\%), in 2011 (103, 4\%), and 2012 (113.1\%) of which were included in the criteria is very effective. That means that the performance of the KPP Pratama Manado is very good because it can meet the set targets, and the KPP Pratama Manado should be able to continue to defend it.
\end{abstract}

Keywords: Tax, Effectiveness, Inspection, Settlement, Revenue 


\section{PENDAHULUAN}

\section{Latar Belakang}

Saat ini Indonesia mengalami berbagai permasalahan di berbagai sektor khususnya sektor ekonomi dan untuk tetap dapat bertahan dan memperbaiki kondisi yang ada maka pajak merupakan salah satu potensi penerimaan dalam negeri yang menjadi prioritas utama karena mampu mendominasi penerimaan negara.

Berdasarkan perundang-undangan perpajak di Indonesia saat ini dalam melaksanakan pemungutan pajak menganut sistem self assesment. Sistem pemungutan ini mempunyai arti bahwa besarnya pajak yang terutang dipercayakan kepada Wajib Pajak (WP) itu sendiri, dimana WP harus melaporkan secara teratur seluruh jumlah pajak yang terutang dan jumlah pajak yang telah ditentukan dalam peraturan perundang-undangan perpajakan.

Oleh sebab itu untuk mendukung keberhasilan diterapkannya sistem self assesment salah satu hal mendasar yang harus dilakukan adalah melaksanakan penegakan hukum (law enforcement) perpajakan. Penegakan pelaksanaan penegakan hukum pajak secara tegas dan konsisten akan mampu menciptakan kepatuhan yang lebih baik dari wajib pajak dan akan bermuara pada peningkatan penerimaan dari sektor pajak. Oleh karena itu terhadap Wajib Pajak yang melakukan kecurangan dan lalai akan pemenuhan kewajibannya perlu dilakukan pemeriksaan untuk menguji kepatuhan dan menegakkan peraturan perpajakan (law enforcement) yang mempunyai kekuatan hukum memaksa sesuai dengan prosedur yang telah ditetapkan dalam UU perpajakan.

Dalam skala mikro, kondisi kota Manado sangat strategis dengan penduduk yang cukup padat dan memiliki mobilitas kegiatan ekonomi yang tinggi sehingga memberi peluang untuk menggali potensial, karena itu sangat mungkin ada wajib pajak yang tidak membayar tepat waktu atau bahkan tidak membayar sama sekali.

Dari uraian diatas penulis merasa untuk melakukan penelitian mengenai efektivitas penyelesaiaan dan penerimaan atas hasil pemeriksaan pajak penghasilan orang pribadi. Oleh karena itu, penulis akan melakukan penelitian dengan judul "Efektivitas Penyelesaian Dan Penerimaan Atas Hasil Pemeriksaan Pajak Penghasilan Orang Pribadi (Studi kasus pada KPP Pratama Manado)"

\section{Tujuan Penelitian}

1. Untuk mengetahui Efektivitas berdasarkan target dan realisasi surat perintah pelaksanaan pemeriksaan (SP2) Pajak di KPP Pratama Manado.

2. Untuk mengetahui Efektivitas penyelesaian dan penerimaan pemeriksaan pajak penghasilan khususnya PPh Orang Pribadi (PPh Orpri) di KPP Pratama Manado.

\section{TINJAUAN PUSTAKA}

\section{Konsep Akuntansi}

Menurut (Horngren dan Harrison, 2007:4) "Accounting is the information system that measures business activity, processes the data into reports and communicates the results decisioan makars." Akuntansi adalah sistim informasi yang mengukur aktifitas bisnis, memproses data menjadi laporan dan mengkomunikasikan hasilnya kepada para pembuat keputusan.

American Accounting Association, mendefinisikan akuntansi sebagai "Proses mengidentifikasikan, mengukur, dan melaporkan informasi ekonomi, untuk memungkinkan adanya penilaian dan keputusan yang tegas bagi mereka yang menggunakan informasi tersebut."

Dari batasan tersebut dampak arah tujuan akuntansi itu sendiri, yaitu menyajikan informasi ekonomi (economic information) dari suatu economic entity (entitas atau kesatuan ekonomi) kepada pihak-pihak yang berkepentingan (stakeholder) atas informasi ekonomi. Agar akuntansi dapat menghasilkan informasi ekonomi, diperlukan adanya suatu metode pencatatan, penggolongan, analisis, pengendalian transaksi kegiatan keuangan, dan pelaporan keuangan perusahaan.

\section{Pengertian Pajak}

Menuru (Mardiasmo 2009: 1) Pajak adalah iuran rakyat pada kas Negara berdasarkan undang-undang (yang dapat dipaksakan) dengan tiada mendapat jasa timbal (kontaraprestasi) yang langsung dapat di tunjukan dan digunakan untuk membayar pengeluaran umum. Pajak dipungut berdasarkan norma-norma hukum guna menutup biaya produksi barang-barang dan jasa kolektif untuk mencapai kesejahteraan umum. Jadi, Pajak 
merupakan hak prerogatif pemerintah, iuran wajib yang dipungut oleh pemerintah dari masyarakat (wajib pajak) untuk menutupi pengeluaran rutin negara dan biaya pembangunan tanpa balas jasa yang dapat ditunjuk secara langsung berdasarkan undang-undang.

\section{Fungsi dan Peran Pajak}

Sebagaimana telah diketahui ciri-ciri yang melekat pada pengertian pajak dari berbagai definisi, maka fungsi dan peran pajak sangat penting bagi negara yang mana pajak tersebut dipungut berdasarkan Undangundang serta aturan pelaksanaannya bersifat dapat dipaksakan.

(Waluyo, 2011:6) mengemukakan "minimal ada dua definisi atau fungsi pajak yaitu:

1. Fungsi penerimaan (budgeter)

Pajak berfungsi sebagai sumber dana yang diperuntukan bagi biayaan pengeluaran-pengeluaran pemerintah. Sebagi contoh: dimasukannya pajak dalam APBN sebagai penerimaan dalam negeri.

2. Fungsi mengatur (regular)

Pajak berfungsi sebai alat untuk mengatur atau melaksanakan di bidang social dan ekonomi. Sebagai contoh:dikenakannya pajak yang lebih tinggi terhadap minuman keras.dapat ditekan dan demikian pula terhadap barang mewah.

\section{Pengertian Pemeriksaan Pajak}

Menurut (Wirawan, 2010:137), terhadap wajib pajak yang akan diperiksa sebaiknya juga mengetahi adanya hak dan kewajiban dalam proses pemeriksaan untuk menghindari adanya kemungkinan terjadinya kasalah pahaman antara pemeriksa pajak dan wajib pajak.

Pengertian pemeriksaan pajak telah diatur dalam pasal 1 angka 24 UU nomor 6 tahun 1983 tentang Ketentuan Umum dan Tata Cara Perpajakan sebagaimana telah diubah terakhir dengan UU nomor 16 Tahun 2009 yang menyatakan bahwa: "Pemeriksaan adalah serangkaian kegiatan untuk mencari, mengumpulkan, dan mengolah data dan atau keterangan lainnya untuk menguji kepatuhan pemenuhan kewajiban perpajakan dan untuk tujuan lain dalam rangka melaksanakan ketentuan perundang-undangan perpajakan.

\section{Ruang Lingkup Pemeriksaan}

Meneurut (waluyo, 2009:321) Mengacu pada peraturan menteri keuangan No. 199/PMK03/2007 tentang tatacara pemeriksaan pajak, membedakan jenis pemeriksaan, ruang lingkup, dan keriteria pemeriksaan

\section{Petugas Pelaksana Pemeriksaan Pajak}

Menurut KMK Nomor 545/KMK.04/2000, pemeriksa pajak adalah pegawai negeri sipil di lingkungan Direktorat Jenderal Pajak atau tenaga ahli yang ditunjuk oleh Direktur Jenderal Pajak yang diberi tugas, wewenang, dan tanggung jawab untuk melaksanakan pemeriksaan pajak.

\section{Tinjauan Umum Mengenai Efektivitas}

Menurut (Ervina, 2007:35), untuk mengukur tingkat efektivitas dari suatu sistem kerja dapat juga dengan memberikan peringkat dengan menggunakan skala peringkat. Skala peringkat yang digunakan adalah: (dalam presentase)

1. > 100 sangat efektif

2. 90 - 100 efetif

3. $80-89$ cukup efektif

4. $70-79$ kurang efektif

5. $<69$ tidak efektif

Apabila konsep efektivitas dikaitkan dengan pemeriksaan maka yang dimaksud efektivitas adalah seberapa besar realisasi yang dapat dicapai atas target yang telah ditetapkan oleh pihak KPP Pratama Manado setiap tahunnya untuk memenuhi tujuan yang telah ditetapkan, dengan menggunakan indikator-indikator sebagai berikut:

a. Dari segi penyelesaian dengan berdasarkan pada jumlah Surat Perintah Pemeriksaan (SP2) Pajak selesai mulai tahun 2010 sampai tahun 2012

b. Dari segi penerimaan atas hasil pemeriksaan dengan didasarkan pada jumlah target dan realisasi ketetapan pemeriksaan mulai dari tahun 2010 sampai tahun 2012. 
Tabel .1 Penelitian Terdahulu

\begin{tabular}{|c|c|c|c|c|c|c|c|}
\hline No. & $\begin{array}{c}\text { Nama } \\
\text { penelitih/ } \\
\text { Tahun }\end{array}$ & Judul & Tujuan & $\begin{array}{c}\text { Metode } \\
\text { penelitian }\end{array}$ & Hasil Penelitian & Persamaan & Perbedaan \\
\hline 1. & $\begin{array}{l}\text { Ervina } \\
\text { Krisbianto } \\
(2007)\end{array}$ & $\begin{array}{l}\text { Efektivitas } \\
\text { Pelaksanaan } \\
\text { pemeriksaan } \\
\text { dalam rangka } \\
\text { menigkatkan } \\
\text { penerimaan Negara } \\
\text { dari sektor pajak } \\
\text { (studi kasus kantor } \\
\text { pelayanan pajak } \\
\text { Tulungagung) }\end{array}$ & $\begin{array}{l}\text { Untuk } \\
\text { mengetahui } \\
\text { efaktivitas } \\
\text { pelaksanaan } \\
\text { pemeriksaan } \\
\text { dalam } \\
\text { meningkatkan } \\
\text { penerimaan } \\
\text { Negara dari } \\
\text { sektor pajak dan } \\
\text { faktor-faktor } \\
\text { yang } \\
\text { mendukung dan } \\
\text { penghambat } \\
\text { yang dihadapi } \\
\text { dalam } \\
\text { pelaksanaan } \\
\text { pemeriksaan dan } \\
\text { upaya-upaya apa } \\
\text { yang dilakukan } \\
\text { KPP } \\
\text { Tulungagung } \\
\text { dalam mengatasi } \\
\text { hambatan- } \\
\text { hambatan yang } \\
\text { terjadi. }\end{array}$ & $\begin{array}{l}\text { Deskriptif } \\
\text { dan } \\
\text { Kuantitatif }\end{array}$ & $\begin{array}{l}\text { hasil } \\
\text { penghitungan } \\
\text { efektivitas dari } \\
\text { segi } \\
\text { penyelesaian } \\
\text { yang dihitung } \\
\text { berdasarkan pada } \\
\text { penerbitan dan } \\
\text { realisasi Surat } \\
\text { Perintah } \\
\text { Pemeriksaan } \\
\text { Pajak (SP3) yang } \\
\text { selesai, dimana } \\
\text { 2004 - 2006 } \\
\text { termasuk dalam } \\
\text { kriteria sangat } \\
\text { efektif. }\end{array}$ & $\begin{array}{l}\text { Penelitian } \\
\text { Efektivitas }\end{array}$ & $\begin{array}{l}\text { Tempat } \\
\text { penelitian }\end{array}$ \\
\hline 2. & $\begin{array}{l}\text { Menurut } \\
\text { Indah } \\
\text { Rachmawati } \\
(2006)\end{array}$ & $\begin{array}{l}\text { Faktor-faktor yang } \\
\text { mempengaruhi } \\
\text { efektivitas } \\
\text { pelaksanaan } \\
\text { pemeriksaan untuk } \\
\text { meningkatkan } \\
\text { penerimaan Negara } \\
\text { dari sektor pajak ( } \\
\text { studi kasus KPP } \\
\text { Batu ) }\end{array}$ & $\begin{array}{l}\text { Untuk } \\
\text { mengetahui } \\
\text { efektivitas } \\
\text { pelaksanaa } \\
\text { pemeriksaan } \\
\text { untuk } \\
\text { meningkatkan } \\
\text { penerimaan } \\
\text { Negara dari } \\
\text { sektor pajak dan } \\
\text { faktor-faktor } \\
\text { yang } \\
\text { mempengaruhi } \\
\text { pelaksanaan } \\
\text { pemeriksaan . }\end{array}$ & $\begin{array}{l}\text { Deskriptif } \\
\text { dan } \\
\text { kuantitatif }\end{array}$ & $\begin{array}{l}\text { hasil } \\
\text { penghitungan } \\
\text { efektivitas dari } \\
\text { segi } \\
\text { penyelesaian } \\
\text { yang dihitung } \\
\text { berdasarkan pada } \\
\text { penerbitan dan } \\
\text { realisasi Surat } \\
\text { Perintah } \\
\text { Pemeriksaan } \\
\text { Pajak } \\
\text { (SP3) yang } \\
\text { selesai, dimana } \\
\text { tahun 2003 } \\
\text { termasuk dalam } \\
\text { kriteria kurang } \\
\text { efektif } \\
\text { sedangkan tahun } \\
\text { 2004 dan 2005 } \\
\text { termasuk dalam } \\
\text { kriteria sangat } \\
\text { efektif. }\end{array}$ & $\begin{array}{l}\text { Untuk } \\
\text { mengetahui } \\
\text { faktor-faktor } \\
\text { yang } \\
\text { mempengaruhi } \\
\text { efaktivitas } \\
\text { pelaksanaan } \\
\text { pmeriksaan }\end{array}$ & $\begin{array}{l}\text { Tempat } \\
\text { penelitian }\end{array}$ \\
\hline
\end{tabular}




\section{METODE PENELITIAN}

\section{Jenis Penelitian}

Dalam melakukan penelitian diperlukan penyesuaian dengan pokok permasalahan yang diteliti. Hal ini berguna untuk mendapatkan data dan informasi dalam mendukung suatu penulisan untuk menentukan arah kegiatan sehingga tujuan penelitian dapat tercapai. Penelitian yang digunakan adalah deskriptif. Menurut (Sugiyono, 2011:21) Penelitian deskriptif adalah metode yang digunakan untuk menggambarkan atau menganalisis suatu hasil penelitian tetapi tidak digunakan untuk kesimpulan yang lebih luas.

Penggunaan jenis penelitian deskriptif dalam skripsi ini diharapkan mampu memberikan gambaran dari data-data yang diperoleh mengenai efektivitas penyelesaian dan penerimaan atas hasil pemeriksaan pajak penghasilan orang pribadi di KPP Pratama Manado.

\section{Tempat Penelitian}

Penelitian ini dilakukan di Kota Manado yaitu pada KPP Pratama Manado, khususnya pada seksi pemeriksaan yang mengurusi pemeriksaan terhadap Wajib Pajak yang lalai dalam pemenuhan kewajiban perpajakannya.

\section{Prosedur Penelitian}

Prosedur yang dilakukan dalam penelitian ini adalah sebagai berikut:

1. Menentukan judul dan merumuskan masalah.

2. Mengumpulkan data sesuai permasalahan yang diangkat.

3. Pengumpulkan data melalui wawancara terhadap pihak-pihak yang terkait serta pengambilan data-data pada KPP Pratama Manado untuk mengetahui bagaimana tingkat Efaktivitas pelaksanaan pemeriksaan pajak penghasilan khususnya orang pribadi dan realisasi surat perintah pemeriksaan (SP2) pajak.

4. Mengolah data dan menginterpretasikan hasil pengolahan data.

5. Menarik kesimpulan dan memberikan saran yang dianggap perlu sebagai perbaikan dalam masalah yang ada.

\section{Jenis Data dan Sumber Data \\ Jenis Data}

Data merupakan sekumpulan informasi yang diperlukan untuk pengambilan keputusan. Menurut (kuncoro, 2009:145) jenis data dapat dibedakan menjadi:

a. Data kuantitatif, adalah data yang diukur dalam suatu skala numerik (angka).

b. Data kualitatif, adalah data yang tidak dapat diukur dalam skala numerik.

\section{Sumber data}

sumber data menurut (Kuncoro, 2009:148) yang digunakan pada penelitian pada umumnya ada dua, yaitu:

1. Data primer

Data yang diperoleh dengan survey lapangan dengan menggunakan semua metode pengumpulan data original.

2. Data Sekunder

Data yang telah dikumpulkan oleh lembaga pengumpul data dan dipublikasikan kepada masyarakat pengguna data.

Sumber data yang digunakan dalam penelitian ini adalah data sekunder, yaitu data yang berupa arsip atau dokumen yang dimiliki oleh KPP Pratama Manado selama tahun pajak 2010-2012, kemudian data-data tersebut dianalisa secara deskriptif.

\section{Metode Pengumpulan Data}

Metode pengumpulan data yang digunakan dalam penelitian ini adalah:

1. Studi pustaka, yaitu dengan mempelajari dan memahami sumber informasi baik literatur, artikel, maupun situs di internet yang relevan dan berhubungan dengan pembahasan.

2. Metode dokumentasi yaitu suatu proses untuk memperoleh data-data atau dokumen yang telah dipublikasikan oleh pihak lain yang terkait dengan permasalahan yang sedang diteliti. 


\section{Metode Analisis Data}

Menurut (Ervina, 2007:35) analisis data adalah proses penyederhanaan data ke dalam bentuk yang lebih mudah dibaca dan diinterpretasikan. Metode analisis data yang digunakan dalam penelitian ini adalah Deskriptif. Dalam penelitian ini bertujuan untuk menghitung tingkat efektivitas berdasarkan data dan hasil penelitian yang didasarkan antara lain:

1. Dari segi penyelesaian pemeriksaan yang didasarkan pada pencapaian target dan realisasi atas jumlah Surat Perintah Pemeriksaan Pajak yang selesai setiap tahunnya dengan menggunakan perhitungan sebagai berikut:

$$
\text { Efektivitas }=\frac{\text { Realisasi penyelesaian }}{\text { Target pemeriksaan }+\mathrm{n}} \times 100 \%
$$

Dimana $\mathrm{n}=$ jumlah tunggakan pembayaran pajak yang terjadi dari pemeriksaan di tahun sebelumnya jika ada.

Realisasi atas Surat Perintah Pemeriksaan Pajak dimana, penyelesaian pemeriksaan dengan berdasarkan jumlah penerbitan SP2 Pajak.

2. Dari segi penerimaan atas hasil pemeriksaan yang didasarkan pada pencapaian target dan realisasi atas ketetapan pemeriksaan setiap tahunnya dengan menggunakan rumus sebagai berikut:

$$
\text { Efektivitas }=\frac{\text { Realisasi pemeriksaan }}{\text { Target pemeriksaan }+\mathrm{n}} \times 100 \%
$$

Dimana $\mathrm{n}=$ jumlah tunggakan pembayaran pajak yang terjadi dari pemeriksaan di tahun sebelumnya jika ada.

Realisasi atas ketetapan pemeriksaan dimana, besarnya jumlah penerimaan atas hasil pemeriksaan, berdasarkan penerbitan SP2 Pajak.

\section{HASIL PENELITIAN DAN PEMBAHASAN}

\section{Deskripsi Objek Penelitian}

Sebelum modernisasi birokrasi di bidang perpajakan, Kantor Pelayanan Pajak Manado merupakan instansi vertikal Direktorat Jenderal Pajak Kanwil Sulbagut dan Sulbaguteng, yang bernaung di bawah Departemen Keuangan Republik Indonesia. Tugas dari Kantor Pelayanan Pajak Manado adalah melaksanakan sebagian dari tugas-tugas pokok Direktorat Jenderal Pajak, dalam mengelola penerimaan negara.

Pengelola yang berasal dari pajak-pajak negara ini, meliputi administrasi penerimaan, pajak negara, ekstensifikasi pajak dan penetapan, penagihan pajak negara serta masalah-masalah lain yang berkenan dengan permohonan keberatan dan restitusi pajak negara.

Kantor Pelayanan Pajak Manado berdiri pada pertengahan tahun 1959, yang merupakan pemecahan dari Kantor Pelayanan Pajak Makassar, dimana pada waktu itu menggunakan istilah Kantor Inspeksi Keuangan.

Untuk daerah Sulawesi Utara, meliputi Sulawesi Utara dan Sulawesi Tengah yang dalam perkembangan selanjutnya, pada tahun 1969 diubah menjadi Kantor Inspeksi Pajak, dengan wilayah kerja meliputi Sulawesi Utara dan Sulawesi Tengah.

Dengan semakin berkembangnya potensi perekonomian Sulawesi pada umumnya dan Sulawesi Utara dan Sulawesi Tengah pada khususnya, pada tahun 1979, Kantor Inspeksi Pajak Manado oleh Kantor Pusat DJP dibagi menjadi dua, yaitu Kantor Inspeksi Pajak Manado dan Kantor Inspeksi Pajak Palu. Dengan terbaginya Kantor Inspeksi Pajak Manado menjadi dua wilayah kerja, maka dengan demikian terlihat jelas pembagian wilayah administrasinya. sedangkan Kantor Inspeksi Pajak Manado wilayah kerjanya berkurang.

Pada tahun 1989, pemerintah menetapkan penggantian nama Kantor Inspeksi Pajak menjadi Kantor Pelayanan Pajak. Dengan demikian berubah pula nama Kantor Inspeksi Pajak Manado, menjadi Kantor Pelayanan Pajak Manado. Kemudian dengan adanya pertumbuhan ekonomi dan meningkatnya jumlah Wajib Pajak yang potensial, di wilayah Sulawesi Utara dan Sulawesi Tengah, maka pada tahun 1989, Kantor Pelayanan Pajak Manado oleh Kantor Pusat dibagi menjadi tiga wilayah kerja yaitu, Kantor Pelayanan Pajak Manado, Kantor Pelayanan Pajak Gorontalo, dan Kantor Pelayanan Pajak Luwuk. Dengan demikian berkurang 
pula wilayah administrasi dan wilayah kerja Kantor Pelayanan Pajak Manado. Sejak adanya modernisasi birokrasi di bidang perpajakan, Kantor Pelayanan Pajak Manado diubah namanya menjadi Kantor Pelayanan Pajak Pratama Manado, yang berada di bawah Kantor Wilayah DJP Sulawesi Utara, Tengah, Gorontalo, dan Maluku Utara.

Kantor Pelayanan Pajak Pratama Manado, diresmikan oleh Menteri Keuangan Republik Indonesia yakni, Sri Mulyani Indrawati, pada bulan November 2008 di Bukit Tinggi bersamaan dengan KPP Pratama di Lingkungan Kanwil DJP Suluttenggo \& Malut, Kanwil DJP Nusa Tenggara, dan Kanwil DJP Papua \& Maluku. Saat mulai beroperasinya KPP Pratama Manado adalah pada tanggal 1 Desember 2008.

\section{Hasil Penelitian}

\section{Target dan Realisasi Surat Perintah Pemeriksaan Pajak}

Pada Tabel 4.1 ditampilkan target dan realisasi surat perintah pemeriksaan pajak KPP Pratama Manado.

Tabel 4.1

Data Penyelesaian SP2 Pajak PPh Orang Pribadi KPP Pratama Manado Tahun 2010-2012

\begin{tabular}{ccc}
\hline Tahun & Target (SP2) & Realisasi (SP2) \\
\hline 2010 & 21 & 21 \\
\hline 2011 & 39 & 39 \\
\hline 2012 & 4 & 4 \\
\hline
\end{tabular}

Sumber: KPP Pratama Manado (diolah)

Dari Tabel 4.1 berdasarkan jumlah penerbitan SP2 Pajak kepada wajib pajak yang selesai diperiksa, dapat dilihat terdapat kenaikan Surat Perintah Pemeriksaan (SP2) pajak yang diterbitkan KPP Pratama Manado dari tahun 2010 ke tahun 2011, namun terdapat penurunan penerbitan Surat Perintah Pemeriksaan (SP2) pajak pada tahun 2012, karna pada tahun sebelumnya penerbitan SP2 Pajak dilaksanakan oleh bagian fungsional namun pada tahun 2012 penerbitan SP2 Pajak dilaksanakan oleh bagian satgas KPP Pratama Manado .

\section{Data Realisasi Jumlah Penerimaan Yang Didasarkan Pada Pencapaian Target dalam penerbitan SP2} Pajak

Pada tabel 4.2 ditampilkan data berdasarkan realisasi jumlah penerimaan atas hasil pemeriksaan yang didasarkan pada pencapaian target atas surat perintah pemeriksaan pajak KPP Pratama Manado.

Tabel 4.2

Data Realisasi Jumlah Penerimaan Yang Didasarkan Pada Pencapaian Target PPh Orang Pribadi KPP Pratama Manado Tahun 2010-2012

\begin{tabular}{ccc}
\hline Tahun & Target $(\mathbf{R p})$ & Realisasi (Rp) \\
\hline 2010 & 401.500 .000 & 408.851 .215 \\
\hline 2011 & 441.900 .000 & 457.228 .400 \\
\hline 2012 & 190.250 .000 & 215.100 .869 \\
\hline
\end{tabular}

Sumber: KPP Pratama Manado (diolah)

Dari Table 4.2 berdasarkan realisasi jumlah penerimaan atas hasil pemeriksaan yang didasarkan pada pencapaian target atas Surat Perintah Pemeriksaan (SP2) Pajak, yang diselesaikan pada tahun 2010 sampai 2012 dapat dilihat bahwa, tahun 2010 sampai 2012 dari hasil penerimaan mampu mencapai target yang telah ditetapkan. Pada tahun 2011 berdasarkan jumlah penerimaan pemeriksaan yang dilakukan ditahun sebelumnya, KPP Pratama Manado sudah dapat menaikan penerimaan dari hasil pemeriksaan pajak dan Pada tahun 2012 terjadi penurunan penerimaan dari hasil pemeriksaan, karna berkurangnya penerbitan Surat Perintah Pemeriksaan (SP2) pajak, namun pada tahun 2012 jumlah penerimaan mampu mencapai target yang telah ditetapka. 


\section{Perhitungan Efektivitas Pelaksanaan Pemeriksaan Pajak}

Efektivitas pelaksanaan pemeriksaan dari segi waktu penyelesaian dengan berdasarkan penerbitan ditambah saldo tunggakan jika ada, dan realisasi atas Surat Perintah Pemeriksaan (SP2) Pajak.

\section{Penghitungan Efektivitas Pelaksanaan Pemeriksaan Pajak Berdasarkan Target dan Realisasi SP2 Pajak} Penghitungan Tingkat Efektivitas dari tahun 2010-2012 adalah sebagai berikut :

a) Tahun 2010

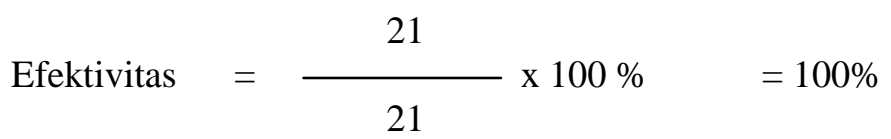

b) Tahun 2011

$$
\text { Efektivitas }=\frac{39}{39} \times 100 \%=100 \%
$$

c) Tahun 2012

$$
\text { Efektivitas }=\frac{4}{4} \times 100 \%=100 \%
$$

Dari hasil penghitungan diatas dapat diketahui bahwa tingkat efektivitas yang dicapai berdasarkan penerbitan dan realisasi atas SP2 Pajak sebagai berikut:

a. Pada tahun 2010 yang dicapai adalah sebesar $100 \%$ maka tingkat efektivitas yang di capai termasuk dalam kriteria efektif.

b. Pada tahun 2011 yang dicapai adalah sebesar 100\% maka tingkat efektivitas yang di capai termasuk dalam kriteria efektif.

c. Pada tahun 2012 yang dicapai adalah sebesar $100 \%$ maka tingkat efektivitas yang di capai termasuk dalam kriteria efektif.

\section{Penghitungan Efektivitas Berdasarkan Realisasi Jumlah Penerimaan Yang Didasarkan Pada Pencapaian Target}

Penghitungan efektivitas Pelaksanaan dari segi penerimaan atas hasil pemeriksaan adalah sebagai berikut :

a) Tahun 2010

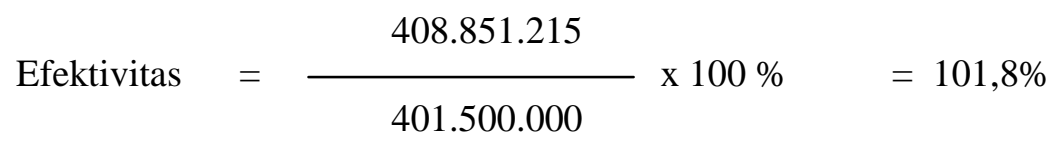

b) Tahun 2011

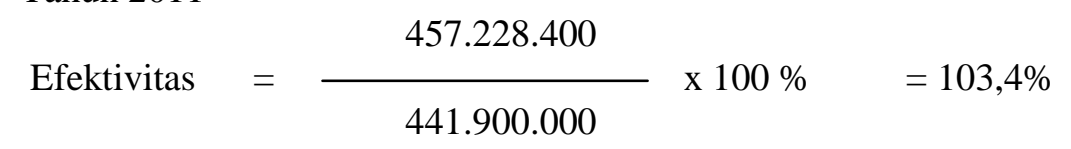

c) Tahun 2012

$$
\text { Efektivitas }=\frac{215.100 .869}{190.250 .000} \times 100 \%=113,1 \%
$$

Dari hasil penghitungan dapat diketahui bahwa tingkat efektivitas yang dicapai berdasarkan targetdan realisasi dari penerimaan atas hasil pemeriksaan sebagai berikut :

a) Pada tahun 2010 yang dicapai adalah sebesar 101,8\% maka tingkat efektivitas yang dicapai termasuk dalam kriteria sangat efektif.

b) Pada tahun 2011 yang dicapai adalah sebesar 103,4\% maka tingkat efektivitas yang dicapai termasuk dalam kriteria sangat efektif.

c) Pada tahun 2012 yang dicapai adalah sebesar 113,1\% maka tingkat efaktivitas yang dicapai termasuk dalam criteria sangat efektif. 


\section{Pembahasan}

Efektivitas Penyelesaian SP2 Pajak PPh Orang Pribadi KPP Pratama Manado Tahun 2010-2012

Pada Tabel 4.3 ditampilkan efektivitas penyelesaian SP2 Pajak PPh Orang Pribadi KPP Pratama Manado.

Tabel 4.3

Efektivitas Penyelesaian SP2 PPh Orang Pribadi

KPP Pratama Manado Tahun 2010-2012

\begin{tabular}{ccc}
\hline Tahun & Presentase (\%) & Kriteria \\
\hline 2010 & $100 \%$ & Efektif \\
\hline 2011 & $100 \%$ & Efektif \\
\hline 2012 & $100 \%$ & Efektif \\
\hline
\end{tabular}

Sumber: (diolah)

Dari hasil penghitungan diatas dari tahun 2010-2012 mempunyai tingkat efektivitas yang sama yaitu sebesar 100\%, karena KPP Pratama Manado selalu bisa menyelesaikan Surat Perintah Pemeriksaan (SP2) Pajak, dalam jangka waktu yang telah ditentukan yaitu satu tahun, makanya tidak ada penumpukan SP2 Pajak tahun sebelumnya yang harus diakumulasikan pada tahun berikutnya. Selain itu Wajib Pajak kooperatif dalam melaksanakan pemeriksaan pajak sehingga tidak ada kesulitan yang terlalu mengkhawatirkan pemeriksa. Itu berarti kinerja dari KPP Pratama Manado sudah baik karena bisa memenuhi target yang telah ditentukan, dan sebaiknya KPP Pratama Manado bisa mempertahankan hal tersebut.

Wajib Pajak kooperatif yaitu WP memiliki pengetahuan yang cukup mengenai pajak dan tingkat kepatuhan yang relatif tinggi dengan selalu membayar pajak secara tepat waktu serta dalam pelaksanaan pemeriksaan pajak tidak mempersulit fiskus seperti tidak menolak untuk menunjukkan dokumen/buku/catatan yang diperlukan oleh pemerikasa, memberikan kesempatan pemeriksa untuk masuk kedalam ruangan yang dianggap penting oleh pemeriksa guna memperlancar pemeriksaan, dan memberikan keterangan secara jelas baik secara lisan maaupun tertulis kepada pemeriksa.

Efektivitas Realisasi Jumlah Penerimaan Yang Didasarkan Pada Pencapaian Target Berdasarkan SP2 Pajak

Pada tabel 4.4 ditampilkan efektivitas realisasi jumlah penerimaan yang didasarkan pada pencapaian target berdasarkan SP2 Pajak PPh orang pribadi KPP Pratama Manado.

Tabel 4.4

Efektivitas Realisasi Jumlah Penerimaan Yang Didasarkan Pada Pencapaian Target Berdasarkan SP2 Pajak PPh Orang Pribadi KPP Pratama Manado Tahun 2010-2012

\begin{tabular}{ccc}
\hline Tahun & Presentase $(\%)$ & kriteria \\
\hline 2010 & $101,8 \%$ & Sangat Efektif \\
\hline 2011 & $103,4 \%$ & Sangat Efektif \\
\hline 2012 & $113,1 \%$ & Sangat Efektif \\
\hline
\end{tabular}

Sumber: (diolah)

Dimana terjadi kenaikan pada tahun 2010 (101,8\%), $2011(103,4 \%)$ dan $2012(113,1 \%)$ maka tingkat efektivitas yang dimiliki termasuk dalam kriteria sangat efektif. Karena adanya kerjasama yang baik antara petugas pemeriksa dengan Wajib Pajak, baik yang mempunyai penghasilan besar, menengah, dan kecil. Mereka memiliki tingkat kesadaran dan kepatuhan yang relatif tinggi mengenai kewajiban perpajakannya. Padahal fokus utama dari pemeriksaan adalah Wajib Pajak yang tidak patuh dan yang melakukan penghindaran/ penggelapan pajak yang cukup tinggi, yang sebagian besar adalah WP besar dan menengah.

Berarti pihak KPP Pratama Manado sudah cukup berhasil melakukan pendekatan dengan metode personal persuasive terhadap WP menengah dan kecil untuk kooperatif terhadap pelaksanaan pemeriksaan pajak. Yang dimaksud dengan metode personal persuasif adalah dengan melakukan pemantauan ke lapangan dengan melakukan kunjungan langsung ke tempat usaha atau ketempat tinggal WP untuk melihat kondisi yang sebenarnya terjadi.

Maka bisa dikatakan bahwa kedua indikator yang digunakan dalam pengukuran tersebut mempunyai keterkaitan yang melengkapi antara indikator satu dengan indikator yang lainnya. Indikator yang pertama 
merupakan penentu atas standar prestasi setiap pemeriksa pajak di KPP Pratama Manado yang telah ditetapkan oleh pusat Direktorat Jenderal Pajak. Sehingga, penghitungan efektivitas pelaksanaan pemeriksaan tidak dapat ditentukan hanya dengan menggunakan satu indikator saja tanpa melihat indikator lainnya.

\section{KESIMPULAN DAN SARAN}

\section{Kesimpulan}

Dengan berdasarkan uraian dari hasil penelitian dan pembahasan maka dapat disimpulkan sebagai berikut :

Hasil penghitungan Efektivitas pelaksanaan pemeriksaan pajak penghasilan khususnya $\mathrm{PPh}$ orang pribadi dan realisasi surat Perintah Pemeriksaan (SP2) Pajak di KPP Pratama Manado, dari segi penyelesaian yang dihitung berdasarkan pada penerbitan dan realisasi (SP2) Pajak yang selesai, dimana tahun 2010-2012 mempunyai tingkat efektivitas yang sama yaitu termasuk dalam kriteria efektif dengan presentase $100 \%$ dan Hasil penghitungan efektivitas dari segi penyelesaian penerimaan atas hasil pemeriksaan yang dihitung berdasarkan target dan realisasi SP2 Pajak, dimana mempunyai tingkat Efektivitas pada tahun 2010 (101,8 \%), tahun $2011(103,4 \%)$, dan tahun $2012(113,1 \%)$ yang semuanya termasuk dalam kriteria sangat efektif. Atas koordinasi yang baik antara pemeriksa dan wajib pajak pada saat dilakukannya pemeriksaan pajak sehingga tidak ada kesulitan yang terlalu mengkhawatirkan petugas pemeriksa. Itu berarti bahwa kinerja dari KPP Pratama Manado sudah sangat baik karena dapat memenuhi target yang telah ditentukan, dan sebaiknya KPP Pratama Manado dapat terus mempertahankannya.

\section{Saran}

Berdasarkan hasil penelitian dan pembahasan, ada beberapa saran yang dapat diberikan oleh penulis untuk KPP Pratama Manado agar supaya bisa digunakan untuk meningkatkan penerimaan pajak atas hasil pelaksanaan pemeriksaan, yaitu :

1) Melaksanakan penyuluhan kepada masyarakat dengan pihak-pihak yang terkait mengenai informasi tentang perpajakan terbaru, sehingga dapat diharapkan pengertian dan kesadaran masyarakat tentang pajak semakin meningkat.

2) Meningkatkan kualitas dan kuantitas dari sumber daya manusia seperti pemeriksa pajak dengan memberikan kompensasi dan intensif yang mencukupi agar supaya kinerja pemeriksa dalam melaksanakan pemeriksaan bisa lebih optimal.

3) Transparansi dalam proses pelaksanaan tugas dan penggunaan hasil penerimaan pajak sehingga dapat diharapkan antusias yang baik dari masyarakat dalam membayarkan pajak. 


\section{DAFTAR PUSTAKA}

Ervina, 2007. Efektivitas pelaksanaan pemeriksaan dalam rangka meningkatkan penerimaan Negara dari sector pajak.

Horngren, C.T, Harrison, Jr. (2007), Accounting, Pearson Prentice Hall, New Jarsey

Kuncoro, mudrajat. 2009. Metode Riset Untuk Bisnis dan Ekonomi. Bagaimana Menelitih dan Menulis Tesis? Edisi 3. Penerbit Erlangga. Jakarta

Mardiasmo, Perpajakan. Edisi/Revisi 2009, Andi Yogyakarta

Keputusan Menteri Keuangan Nomor KMK 545/KMK.04/2000. Tentang Tata Cara Pemeriksaan Pajak

Undang-undang Nomor 16 Tahun 2009. Tentang Ketentuan Umum dan Tata Cara Perpajakan.

Waluyo, Akuntansi Pajak. Edisi 2. 2009. Salemba Empat.

Waluyo, Perpajakan Indonesia. Edisi 10/2011 Salemba Empat.

Wirawan \& Richard, Hukum Pajak, Edisi 5/ Revisi 2010. Salemba Empat.

Sugiyono, 2011. "Metode Penelitian Dan Bisnis", Alfabeta. Bandung 